\title{
Customary Rights and Societal Stakes of Large-Scale Tobacco Cultivation in Malawi
}

\author{
Alois Mandondo and Laura German
}

\begin{abstract}
This study investigates how diverse dimensions of tenure and rights to land and forest resources have shifted in relation to expanded investments in tobacco, as well as the distribution of associated social, economic and environmental costs and benefits at both local and societal scales. The study focuses on the miombo woodlands of southern Africa, with particular reference to Malawi. It uses a wide variety of methods, including detailed group discussions, desk study and informal interviews. Assessments reflect mixed fortunes across a range of sectors and scales. At the local level, the expansion of tobacco engenders fundamental shifts in customary rights, disrupting crucial livelihood and safety net functions of forested lands. Forests also bear the brunt of tobacco expansion, compounding the effects of sharply rising patterns of displacement of woodland with extraction of wood for curing and the construction of barns. Whilst tobacco-induced deforestation may be localized, the mostly negative ecological externalities associated with it may - because of the public goods nature of impaired ecological services - extend way beyond the confines of the local. However, tobacco remains the major engine for economic growth and development in Malawi, its forest and ecological and other impacts notwithstanding - with the identification of strategies for re-orienting the development onto a more sustainable path remaining a major unresolved challenge.
\end{abstract}

Keywords: Tobacco; investment; customary rights; miombo woodlands; Malawi

\section{Introduction}

The bulk of the research on expanded investments in tobacco in the miombo woodlands of southern Africa, particularly those of Malawi, has focused on economic dimensions (Jaffee 2003, Koester et al 2004, Maleta 2004, Nsiku and Botha 2007, Poulton et al 2007) and environmental impacts, particularly on forests (French 1986, Bunderson and Hayes 1997, Geist 1997, Gossage 1997, Geist et al 2006) - with the former dominating. Although increased investments in tobacco may create new opportunities for local livelihoods and national economies, they also carry the threat of appropriation of land and resources from poor people who depend directly on these assets at the local level (Vermeulen and Cotula 2010). This study investigates how diverse dimensions of tenure and rights to land and forest resources have shifted in relation to expanded investments in tobacco, as well as the distribution of associated social, economic and environmental costs and benefits at both local and societal scales.

The study's provenance is within the emerging area of rights-based approaches to land-based investments (Colchester and Ferrari 2007). The full spectrum of rights impinged on by land based investments may span from those relating to people, to those relating to resources, to those mediating people-resource relations, often with those most dependent on the resources ending up the biggest losers (Vermeulen and Cotula 2010). Two sets of rights ultimately determining whether land and resource appropriations emerge as fair or raw deals apply. The first concerns whether basic tenets of procedural justice pertaining to prior consultation and the consent of those with rights displaced would have been secured. The second revolves around distributive justice and people's rights to fair compensation for foregone resource access and assets (Colchester and Ferrari 2007). 
Beyond sheer land loss, impacts of land-based investments endure most in terms of shifts in resource use rights and relations. This is not least because such investments entail replacing existing (usually customary) systems of rights with state-capitalist forms. A property rights approach similar to that proposed by Schlager and Ostrom (1992) provides a useful entry point to characterizing shifts in "bundles" of rights associated with the investments. They distinguish the following sets of rights over resources: access - rights to enter a physically defined area to enjoy non-subtractable benefits; withdrawal - rights to obtain units of a resource; management - rights to regulate internal use patterns and to direct day to day stewardship; exclusion - rights to determine who has access; and, alienation - rights to sell or lease management or exclusion rights.

Extremely appropriative cases combine loss of land with loss of all of the above sets of rights in resources on land lost. Some investments even compound this scenario with loss of control over resources in new areas in which the people would have been displaced to result in what Murphree and Cumming (1991), in their review of land use policy in the African savannas, term a double expropriation. Although the study places emphasis on land tenure and rights, it also tackles the distribution of associated social, economic and environmental costs and benefits - drawing attention to the biggest potential winners and losers. The study employed detailed focus group discussions in two of the country's prime tobacco growing districts (Kasungu and Mchinji) to unravel shifts in tenure and rights and the local distribution of externalities. These were augmented by quantitative analyses from a related study (Mandondo et al. in prep). National level perspectives were mainly captured through desktop study and key informant interviews.

The second section gives a historical overview of the expansion of tobacco investments in Malawi. It highlights how the smallholder sector has traditionally borne the blunt of most such investments not only in terms of suffering land and resource expropriation but also overt discrimination through policies that favoured, first white, and then black elites. The third section considers 'local stakes' associated with globalized trade and investments in tobacco, including the extent to which these shifted customary bundles of rights together with the respective social, economic and environmental externalities applying at that level. Meanwhile, the fourth section tackles the same set of externalities, but at a 'societal' scale. The last section draws all the preceding section together through a discussion that deciphers winners and losers, emphasizing strategies for re-orienting globalized trade and investments in tobacco in Malawi onto a more sustainable and equitable path.

\section{Historical overview}

\section{From an elitist production model to liberalization}

Malawi began growing and exporting tobacco in 1893, just two years after the British set up a colonial government in the landlocked territory known then as Nyasaland (Matthews and Wilshaw 1992). Until 1920 tobacco was mostly grown on large estates in southern Malawi by European farmers. Settler farmers A.F. Barron and R. Wallace introduced tobacco into the Lilongwe-Kasungu in the central parts of the country in the 1920s, mainly producing tobacco via African tenant farmers they supplied with seedlings and the information, with the tenants selling their tobacco to them at prices predetermined by them. The development became a turning point in the history of tobacco development in Malawi as the Central Province has become the geographical hub of the industry (Matthews and Wilshaw 1992).

Laws and policies enacted over the colonial period defined the commercial growing of tobacco as an exclusive preserve of white settlers on titled land (Tsonga 2004). Complementary policies extended appropriate, albeit preferential, services to the commercial growers - including credit, 
subsidies, infrastructural investments and guaranteed access to markets through quotas. Blacks were offered little or no scope to participate in tobacco growing, other than as tenants and labourers on white-owned estates. Relentless pressure from aspiring black growers, however, necessitated a shift from the policy of overt segregation to one of patronizing goodwill. Restricted numbers of black growers were, under the tutelage of Native Tobacco Board, allowed to grow the less lucrative varieties of the crop, excluding mostly burley and flue cured tobacco. The easement, nevertheless, stipulated the growers to sell their entire produce to the statutory body, usually at prices much less than the prevailing market price (Tsonga 2004).

After Malawi's independence in 1964, many of the expatriate-owned estates became the property of Malawians. Political and economic elites, particularly those closely aligned to the one party political system, joined the ranks of titled land owners (Jaffee 2003, Tsonga 2004). Most elites in the southern region acquired land from expatriate owners in transactions underwritten through the financial support of the Farmers Marketing Board (FMB), a successor of the merger between the Native Tobacco Board and other boards. Dr Banda and his close family, as well as loyal members of the then ruling Malawi Congress Party and its Young Pioneers youth wing, were prominent beneficiaries in the central region. Ironically, the acquisitions were financed through cheap funds iniquitously wrung out of the smallholder sector through two complementary arrangements. The first restricted smallholder farmers from growing and selling premium tobacco varieties to international buyers, and imposed the Agricultural Development and Marketing Cooperative (ADMARC) - a successor to FMB - on them as their sole marketing option. The second conferred ADMARC with the latitude to fix prices in such a way as to cover their costs whilst generating surplus. Much of the accruing rents were channeled to Press Holdings Ltd, a vehicle through which Dr Banda amassed real estate and other investments.

Press Holdings Ltd was a huge conglomerate with subsidiary companies spanning many aspects of the national economy - including Standard Bank, National Insurance Corporation, Malawi Development Corporation, Press Bakeries, Press Transport and Press Agriculture Limited under which was General Farming and Press Farming. The former specialized in flue production under superior (expatriate) management and capital intensive investments, e.g. irrigation. The latter, through which smallholders were also intended to benefit, promoted burley production and was administered by inferior caliber managers, usually local graduates from Bunda College. ${ }^{1}$ Another of Dr Banda's personal pet projects in agriculture was Chamavi, with its activities also concentrated in the Central Province, particularly in Kasungu.

Pressure from the grassroots in the 1980s, and from donors in the early 1990s, ushered reforms that fundamentally changed the structure of tobacco production in Malawi (Jaffee 2003). The former was associated with popular resentment to patronage and elite-based development models, in response to which the government partially relaxed rules governing access to quotas. Small estates of 10-20 hectares were created out of what was considered 'unutilized customary land' and acquired by families to grow tobacco under quota on a leasehold basis. Around 30000 such estates were established during the 1980s, accounting for much of the production registered during that period.

\footnotetext{
${ }^{1}$ Group discussion with Forestry Officers, Kasungu, 12 October 2009.
} 
Donor-induced reforms extended the privileges of quota-based tobacco production to the smallholder sector through a system of licenses awarded to clubs of between 10-30 members, bringing on stream over 350000 growers. In part because of the ensuing competition the overall share of small/medium and large estates has declined since the mid-1990s, resulting in most of them collapsing or scaling down significantly. Jaffee (2003) estimates that some $40-50 \%$ of the estates which had been producing tobacco in the early 1990s gave up production altogether, whilst others drastically scaled back on their operations. Estates creaking under the weight of high overheads and managerial inefficiency, particularly those belonging to absentee owners, are cited as among the key victims. These were more prone to side-marketing in a context in which parallel liberalizing reforms had conferred intermediate buyers with the bridging role of purchasing tobacco directly from growers at the farm gate. Overall, between liberalization and 2000, customary leasehold estates and medium-large (elite) estates production fell from around 35000 to 20000 tons per annum whilst smallholder production rose to account for $70 \%$ of the national crop - contributing to "improvement" in social and poverty indicators registered in second half of the 1990s.

\section{"Improvement" Within the Context of a Double Expropriation}

Notions of tobacco as bringing 'improvement' mask its other darker sides, the most severe of which is its impact on local people's land and resource rights. The phenomenon is closely tied to the emergence of colonial land use policy, which entailed expropriating land and resources from customary systems to emerging state-capitalist forms, including large scale agricultural estates. Usually this was done under the pretext that the appropriated land was unutilized, with this remaining the basis on which the majority of the elite estates were created after independence under the Banda regime, particularly during the 1970s and 1980s. This article uses evidence from two sites in the prime tobacco growing areas to show how elite and commercial interests in tobacco have impinged on the land and resource rights of local communities. Processes entailed are more akin to Murphree and Cumming's (1991) double expropriation.

\section{“Local stakes" vis-à-vis Globalized Trade and Investment}

\section{Land transfer to estates}

Despite the diversity of scenarios, this study considered a case involving wholesale land loss to General Farming - a tobacco-growing parastatal in Kasungu - and partial loss of villagers' land to a leaser of a long-established private estate in Mchinji. The former entailed arbitrary displacement, effected without prior informed consent, affecting close to 100 households. Three of the four affected villages claimed receiving no compensation, with sentiment in the last divided over whether the banana plants they had received were intended as compensation for loss of land or replacement for plants destroyed when the eviction was enforced. Villagers offered little or no resistance for fear of Dr Banda's regime: a widespread belief then was that "the Ngwazi could see, hear and smell everything in all corners of the country". Land was also acquired without consultation and prior informed consent in the Mchinji case in which about 80 households lost $50 \%$ of their village land, of mostly fertile soil patches and wetlands. The transfer was facilitated through a secretive deal between the leaser and the village head, and consummated under the pretext that the land in question was 'unutilized', as required by 
supporting state laws. Ordinary villagers received no compensation for the loss of land and assets on it, including fruit trees such as mangoes, paw paws and bananas. The headman dismissed this assertion and claimed most people had moved out of their own volition after receiving compensation of a bag of fertilizer each.

Quantitative analyses showed that land owned or exclusively accessed by households - which was lost to the estates - averaged 7.20 acres, consisting of croplands, wetlands and woodlands. The croplands were either permanently committed to crops or alternated between cultivation and fallow across seasons. Wetlands - of generally far smaller sizes than the croplands - were either used as permanent pastures or alternated between cultivation, pasture and fallow. Some households also owned or enjoyed the exclusive use of patches of woodland that could be alternatively used for cultivation, pasture, fallow or maintained as permanent pastures or woodlands. Rights over all these landholdings were stated as private within a tenure regime invariably listed as communal.

Lost lands also included those which villagers held communal access rights within a customary tenure setting. Communal landholdings that could be accessed and used by a household were estimated on average far bigger (mean $=35.62$ acres) than the above exclusively owned or accessed lands. The communally used plots comprised mainly of wetlands and woodlands under various forms of use. Use of the former included cultivation that alternated with seasonal fallow and pasture - or pasture or woodland in permanent form. The woodlands were formerly exclusively used as permanent pastures or maintained as permanent woodlands. The full extent of land lost could, however, by far exceed assessments captured at the household level. All respondents indicated that considerable swathes of communal were also lost to the estates. No definitive figures could be obtained about the actual sizes of these other lost lands, with estimations invariably stated as "extensive".

Drastic reduction in landholdings constitute one of the most acute impacts of loss of land to estates. Household landholdings across the two district sites contracted by a factor of 4 to 5 as a result of land loss. In more nuanced terms, land loss also reduced the range of plots constituting the landholding portfolio considered owned or exclusively accessed by the household. Whereas households could boast owning or exclusively accessing homesteads, croplands, wetlands or even woodlands - land loss whittled this down to a twosome portfolio consisting of only homesteads and permanent croplands. Wetlands and woodlands now lay beyond the purview of what households could claim or exclusively use as their own. This effectively means land loss deprived villagers of the latitude in livelihood conferred through access and ownership of a diverse array of plots scattered across the landscape - including the ability to fallow croplands.

\section{Shifts in customary "bundle" of rights}

If anything, study findings show that land lost to commercial estates was everything except idle. The land was acquired from the respective communities in a highly arbitrary and capricious manner that did not conform to any tenet of procedural justice, including the communities' rights to be consulted, let alone their rights to consent or be fairly and adequately compensated for the loss of the land. There was unanimity in group discussions across both sites that land loss resulted in a near total extinguishment of regimes of rights the villagers had over agricultural 
land - including those to cultivate, graze, make management decisions, exclude others, or to sell or bequeath the land. Whereas smallholders within and across villages used to share various rights in agricultural land, acquiring estates have put in place strict exclusion management regimes. For instance, cattle straying from surrounding villages are impounded to be released upon payment of fines, failing which they get confiscated.

In both group discussions, the distribution of externalities associated with shifts in rights to agricultural land applied to all within the family for all rights except the right to sell, rent or bequeath the land. Externalities associated with loss of cultivation rights invariably included reduced landholdings that necessitated the dropping of some crops, which increased the risk of food insecurity, with all within the family considered equally exposed to the vagaries of food shortages. Reduced grazing rights were associated with increased herding of livestock to prevent them straying, a task acknowledged as shared by all within families. Although the groups generally agreed that all members of families suffer from inability to make management decisions over lost lands, the balance of argument within the Kasungu group was that men suffered more at the level of ego, as they are chief decision makers within families. Small landholdings were reported to leave insufficient room for transferring land to children via inheritance, forcing most young people into leasing land. Divorced women were also noted to bear the blunt of land loss more as in the existing patrilineal system they are expected to return to their parents' homes where they find much of the land already in use.

The group discussants portrayed a system of customary rights to natural forests before land acquisition roughly according with the following characterization. First, the existence of a system guaranteeing all households rights to graze their cattle or withdraw resources such as water and NTFPs, provided they did so within the existing customary norms of civility. Second, a system relying more on reciprocity to regulate resource access and use across different landscape units among different social groups rather than one relying entirely on exclusion management. And lastly, a system allowing for the transfer of land mainly through inheritance than through commercial transactions such as land sales and leasing. The above customary regimes were, on acquisition of the land, superseded by formal title, with the acquiring authorities putting in place strict regimes of exclusion management. Thus, whereas resources such as water were considered God-given resources that could not be denied others, the estates now prohibit surrounding villagers from accessing it. Restricted regimes of access to forest and other resources on land acquired by the estates has spawned scarcity of resources within surrounding communities, triggering tendencies towards their commercialization and denial of access to them to other users.

Gender division of household labour was considered such that women were left most direly saddled by the intra-household distribution of externalities associated with the denial of access to forest and other resources. This was particularly so for rights impinging on the collection of resources such as firewood and water. Exclusion management regimes imposed by estates on access to forest grazing, NTFPs and agricultural land was seen as impacting as severely on women as it did on men and children alike. The shortage of timber associated with land loss was reported to be so acute that most people now have to travel hundreds of kilometers to the government forest at Chikangawa to access the resource, with carpenters singled out as the most direly affected specialist group. 


\section{Magnitude and Distribution of Local Externalities}

\section{Primary benefits arising from the estate}

Benefits arising from the establishment of the General Farming estate in Kasungu appeared very much underplayed in the group discussions. Though employment was mentioned as the most immediately recognizable direct benefit, low levels of remuneration realized from it were such that respondents equated it with "slavery". Benefits of employment were further underplayed through arguments that most tobacco farms usually featured very low complements of local employees of as low as less than 10 per estate, with most of the positions filled by people from other distant areas in Malawi, with the rest being seasonal employees. The estate does not have a preferential policy, in terms of employment or otherwise, that favours those who lost land. In fact, most among those employees that reside on the estate are from the southern region of the country, particularly from areas around Thyllo and Mulanje. They could have been formerly employed in tea estates there but respondents were not sure whether this was the reason why they tended to be favoured as part of the permanent workforce. Opportunities for seasonal employment were considered galore during the peak season - often with the estate operating two shifts of labourers per day. Remuneration levels were considered very low, and estimated at between MK2000-2500 per month for most. Group discussants sharply denied receiving any such benefits in the Mchinji case.

After a belaboured plea from the research team that the research intended to capture balanced views without necessarily trivializing local people's grievances, the following were suggested as additional benefits arising from the estate in Kasungu: source of purchased food in times of hunger; diffusion of agricultural knowledge; skills development, with some among the employed having mastered certain specialist trades; and, access to social infrastructure associated with the estate such as clinics and roads, although respondents indicated that they do pay when they use some of these facilities. No such benefits were mentioned by the Mchinji group where access to food produced in the farm was characterized in negative rather than positive terms: the estate plants early maize on wetlands that villagers lost and sells the maize to the same villagers.

In Kasungu, the scope for the estate as a market for local agricultural produce was considered limited because most of its employees commute to work from surrounding villages. There were more people staying on the estate though in the 1980s, but it fell on bad times throughout the entirety of Muluzi's rule. The estate was a major buyer of wood sourced from surrounding villages but prospects for viably extracting the wood have since been dimmed by increasing wood scarcity. The reverse, in terms of flow of agricultural produce, was seen as holding true in Mchinji; the surrounding villages provided a market for agricultural commodities produced on the farm, particularly green mealies. The estate took over prime wetlands on which former owners used to grow mostly garden crops under irrigation during the dry season. The estate and those leasing wetlands from it fill in the gap by producing the crop for sale in surrounding villages, including among those who suffered land loss.

\section{Social, economic and environmental impacts of shifts in land ownership}


Land pressure is one of the most obvious direct impacts of the acquisitive nature of tobacco expansion in Malawi. Land losers attributed their 'perpetual food insecurity' to their much reduced and inferior landholdings. The food security problem was perceived by the Kasungu land losers group as most impacting on women because they stay at home to look after children, and in circumstances of food insecurity are "psychologically distressed by the cries of starving children". In such scenarios men usually resort to scouting for employment of one form or another, where they may chance upon meals. Moreover, whilst men scouted for off-farm employment (and food), women were left most saddled with the household labour burden, with the burden seen as having been accentuated by land loss.

Land losing participants to group discussions attributed their small landholdings to the expansion of tobacco, and in particular its acquisitive nature. The displacements have compounded pressure for agricultural land forcing people to resort to intensification, reducing crop diversification and acquiring extra land via leasing from others. Wetlands constituted a prized possession that justified the cost of leasing in Mchinji. Prices could range from K3000-5000 per acre per year. Ironically, the adjacent estate also either sub-leases wetlands to the former owners and users of such land, or grows early maize on them to sell to green mealies to them. Underprivileged groups within the community cannot afford to lease land, and hence were considered more prone to food insecurity. The infirm, those chronically ill, and widow and orphan-headed households invariably fell into this group.

Leasing was reported to have fueled internecine intra-familial conflicts within the community. For instance, one youthful participant claimed to have appealed to the District Commissioner to block his father from depriving him and his siblings of an inheritance to the family land. The practice was so deeply entrenched and steeped in corruption that the leases were difficult to reverse once awarded, even via recourse to official intercession, and hence dubbed "a game for the rich". Usually, it was the rich from as far afield as Lilongwe and Blantyre, who get entitlements at the expense of those living within these communities. Although the practice has been banned by traditional leaders the current state of affairs was such that those already leasing land still proceed to sub-lease, either informally or formally.

Most leaseholders deny villagers on customary land access to wood, grass and fodder that villagers would have freely access before the award of the lease. The water picture was mixed as some informants indicated that most leaseholders subscribe to the belief that water is a Godgiven resource that should not be denied to others, whilst others insisted on the contrary. Restrictions imposed by leaseholders on access to water have necessitated villagers to dig wells and boreholes that they may share with others freely, or for a fee. Before the advent of the leasing system people used to enjoy free access to copiously available water resources. Cattle used to drink from natural water sources but the enclosure and barricading of these sources on leasehold land has necessitated that cattle owners water their stock at artificial water sources, where they now have to compete with humans. Other changes include that cattle have to be herded and goats tethered to prevent straying onto leasehold land, where they may be confiscated. Most resources - including land, water, fodder, or even food - shared freely with others before, were now increasingly sold or rented, if not totally denied to others altogether. 
Although the leases were seen as guaranteeing security of tenure to those who could afford them, they were patently detested by the various informant groups with views ranging from: "land was freely given to all of us by God, so why should some among us start selling it"; "lease lands have become insatiable holes into which our capital disappears via confiscation of stray livestock"; and, something akin to "lease boundaries have become iron curtains that deny ordinary people rights of passage on roads that they used to freely use", etc. Others asserted that leases had brought a "culture of enclosure" that promotes individual interest" at the expense of "sense of community".

Quantitative assessments corroborated the assessments emerging from qualitative work. At 30\% - purchases and formal and informal leases have made tremendous inroads at eroding traditional means of acquiring land - including inheritance and allocation by traditional leaders - that accounted for $60 \%$ of how land losers acquired their new lands. The prevalence of acquisition of land through such commercial and quasi-commercial means emerged markedly lower (20\%) in a related village level study in Mchinji (Takane 2005). Perceptions of the impacts of land loss or loss of rights to land and resources on it arising from tobacco expansion also accorded closely with qualitative analyses - with all the above italicized impacts rated as very negative or negative (Table 1). Reduced landholding and the constraint it imposes on ability to fallow land topped the list of adversities, with other impacts in turn arising from reduced access to other resources. The social distribution of externalities reflected gender neutrality at the household level, except for access to potable water - which was considered an adversity most impacting on women via an increased labour burden. Environmental problems reported as having been accentuated by increased land pressure outside the estates included deforestation, soil erosion and these were related to drying up of water sources.

Table 1. Perceptions on the severity of impacts of land loss arising from the expansion of tobacco, and the social distribution of the externalities

\begin{tabular}{|c|c|c|c|c|c|c|}
\hline \multirow[t]{2}{*}{ Impact } & \multicolumn{5}{|c|}{$\begin{array}{l}\text { Nature and severity of impact } \\
\text { (percentage of respondents) }\end{array}$} & \multirow{2}{*}{$\begin{array}{c}\text { Most } \\
\text { affected } \\
\text { (\% of all } \\
\text { respondents) }\end{array}$} \\
\hline & $\begin{array}{c}\text { Very } \\
\text { negative }\end{array}$ & Negative & No impact & Positive & $\begin{array}{c}\text { Very } \\
\text { positive }\end{array}$ & \\
\hline $\begin{array}{l}\text { Access to forest } \\
\text { resources }\end{array}$ & 60 & 40 & 0 & 0 & 0 & $\begin{array}{l}\text { Whole family } \\
(70 \%)\end{array}$ \\
\hline $\begin{array}{l}\text { Ability to fallow } \\
\text { land }\end{array}$ & 70 & 20 & 10 & 0 & 0 & $\begin{array}{l}\text { Whole family } \\
(88 \%)\end{array}$ \\
\hline $\begin{array}{l}\text { Access to potable } \\
\text { water }\end{array}$ & 30 & 30 & 40 & 0 & 0 & $\begin{array}{l}\text { Women } \\
(58 \%)\end{array}$ \\
\hline $\begin{array}{l}\text { Access to water for } \\
\text { gardens }\end{array}$ & 55 & 40 & 0 & 0 & 0 & $\begin{array}{l}\text { Whole family } \\
(55 \%)\end{array}$ \\
\hline $\begin{array}{l}\text { Access to grazing } \\
\text { resources }\end{array}$ & 45 & 40 & 15 & 0 & 0 & $\begin{array}{l}\text { Whole family } \\
(79 \%)\end{array}$ \\
\hline Access to wetlands & 40 & 45 & 15 & 0 & 0 & $\begin{array}{l}\text { Whole family } \\
(77 \%)\end{array}$ \\
\hline $\begin{array}{l}\text { Household } \\
\text { landholdings }\end{array}$ & 70 & 20 & 5 & 5 & 0 & $\begin{array}{l}\text { Whole family } \\
(95 \%)\end{array}$ \\
\hline $\begin{array}{l}\text { Cost of accessing } \\
\text { land }\end{array}$ & 55 & 40 & 5 & 0 & 0 & $\begin{array}{l}\text { Whole family } \\
(96 \%)\end{array}$ \\
\hline Prevalence of land & 35 & 30 & 30 & 5 & 0 & Whole family \\
\hline
\end{tabular}




\begin{tabular}{|l|c|c|c|c|c|l|}
\hline disputes & & & & & & $(86 \%)$ \\
\hline $\begin{array}{l}\text { Agricultural } \\
\text { intensification }\end{array}$ & 5 & 12.5 & 15 & 37.5 & 30 & $\begin{array}{l}\text { Whole family } \\
(97 \%)\end{array}$ \\
\hline Labour burden & 62.5 & 17.5 & 12.5 & 7.5 & 0 & $\begin{array}{l}\text { Whole family } \\
(91 \%)\end{array}$ \\
\hline Crop diversification & 15 & 35 & 27.5 & 12.5 & 10 & $\begin{array}{l}\text { Whole family } \\
(97 \%)\end{array}$ \\
\hline Food security & 12.5 & 10 & 12.5 & 20 & 45 & $\begin{array}{l}\text { Whole family } \\
(97 \%)\end{array}$ \\
\hline
\end{tabular}

\section{Timber sourcing practices by tobacco estates}

\section{Shifts in customary "bundle" rights}

Two contrasting sets of experiences emerged from group discussions with regards to the wood sourcing practices of respective estates from adjacent communal areas - one depicted as unfair and arbitrary, and the other assuming some semblance of 'responsibility'. The former applied with regards to a Banda-era General Farming estate sourcing wood from communities forcibly displaced to make way for the estate's establishment in Kasungu, providing a perfect example a double expropriation effected with little regard to the rights of local communities. As eloquently described by an elderly respondent:

The estate started accessing resources on customary lands in an arbitrary and nonconsultative manner. Initially when resources were relatively still abundant, they just came in with chain saws to start cutting the large trees that existed here without asking for permission. Trees would even be felled from family fields without permission. In some instances pipes were established in fields of some families to abstract water - also without the owners' permission. There was nothing we could do because it was during the Banda years; the fearsome Young Pioneer militias would be present to ensure that those who resisted were severely punished.

Respondents characterized deforestation that occurred as initially gradual when the estate was established, and rampant when the estate was operational. The first phase involved extracting wood suitable for construction, with much of it going into building houses for the white managers. Most preferred species included Pterocarpus angolensis, Diconde spiciformis, Brachystegia spiciformis, Afzelia quansensis etc. As the estate became operational, timber sourcing assumed a non-selective character: the estate's demand for wood for tobacco curing increased, whilst the availability of such wood sharply declined within the villages. Only graveyards were left with woodland during the latter phase. No tree of significant value was left standing in the local landscape, with respondents now ruing tree species that they missed most. These included Julbernadia paniculata for hoe handles, Pterocarpus angolensis (mulombwe) for making coffins and treatment against ringworm and STDs, as well as a favoured wild fruit tree called kasokolowe. Ironically, whilst the estate accesses wood from the communal side, it denies the same communities access to woodland resources on the estate, including even collecting dead wood for firewood. Many first-hand accounts of abusive, albeit not fully substantiated, practices meted on women apprehended by the estate's guards for collecting wood 
were given, including cruel and degrading treatment such as being forced to undress, and demand for sex in exchange for freedom.

In contrast, the sourcing relations between a private estate in Mchinji and the respective local communities were depicted as of a generally benign nature. According to an account given by one of the informants:

Timber sourcing by the estate started some time ago when wood was still relatively more abundant in our village area. The arrangement to buy wood was never instituted at the village level. People clearing their fields would stack some for sale to companies - and this is a practice which has remained in place since then, even if the wood sellers now source wood from communal village land that may not be necessarily theirs. But as of now much of the woodland in areas close to the estates in this area, which are mostly close to the roads - have been wiped of wood. So sourcing teams from the estates now penetrate much deeper into customary lands that still retain significant patches of woodland. Otherwise, only privately owned woodlots comprise sole wood sources close to estates, but these are small and isolated. So timber sourcing is on terms agreed on a willing buyer-seller basis.

Regardless of their nature, wood sourcing did not alter bundles of rights in forest resources on village lands directly, but indirectly through accentuated land and resource pressure - with causal linkages for the later further confounded by other factors like population increase. Thus a combination of factors, including land and resource pressure and population increase, could underlie gradual shifts in customary bundles of rights reported as due to wood sourcing by companies on customary lands, including: increasing tendencies to commercialize products that used to be withdrawn from the forest solely for own consumption e.g. firewood and other NTFPs; more strict exclusion from hitherto freely accessed resources such as grazing; and, more land exchanges occurring through selling and leasing than through inheritance and allocation by customary authorities. These assessments were strikingly similar in the tenure group discussions at both sites.

For grazing, the changing resource use relations were noted to impact more severely for villages not adequately endowed with the resources. Increasing commercialization of land was noted to impact most on divorcees, young people and immigrants. Changing resource use relations applying for fuelwood, including its commercialization and restricted access to it were reported to most impact on women through increased labour for salvaging it from depleted woodland.

\section{Magnitude and distribution of externalities}

Again, the benefits of sourcing wood and other resources by estates from surrounding communal areas emerged muted in discussion groups, regardless of whether sourcing relations were sound or sour. Although the prospects of earning cash from wood sales was acknowledged in Mchinji, declining woodland resources have rendered wood sales insignificant as a viable source of income. Prices of as low as MK500-1000 per mendle of 6 cubic metres of stacked wood prove far from sufficient to fully offset the labour costs associated with gleaning for the wood from depleted woodland. 
The negative effects were more fully amplified in both group discussions, and these included: more social strife associated with declining woodland resource stocks; decreased respect for traditional leaders, with the loss of respect partly accentuated by their failure to fully resolve resource use disputes; free stripping of wood from communal lands by some estates, which deprives local communities of income and generates multipliers of negative environmental impacts, including deforestation, loss of biodiversity, increased soil erosion and erratic rainfall patterns. Respondents in Kasungu attributed the impacts to strictures in resource rights than to scarcity, with the majority attributing the impacts to interactions between these factors (Table 2).

Table 2. Assessments of whether environmental impacts are caused by strictures or scarcity (Kasngu group)

\begin{tabular}{|l|c|l|c|}
\hline Impact & $\begin{array}{l}\text { Strictures in } \\
\text { rights }\end{array}$ & Scarcity & Both \\
\hline Reduced landholdings & & & $\checkmark$ \\
\hline Loss of biodiversity & $\checkmark$ & & \\
\hline Reduced availability of forest resources & $\checkmark$ & & \\
\hline Social conflict & & & $\checkmark$ \\
\hline Soil erosion & & & $\checkmark$ \\
\hline Erratic rainfall patterns & & & $\checkmark$ \\
\hline
\end{tabular}

Coping strategies adopted by smallholders in the face of scarcity of woodland and other resources across both sites included:

- Adoption of agroforestry practices to produce both food and wood crops

- Using - stumps from fields, maize stalks, shrubs, maize cobs, maize husks, chibuku (opaque beer) packets, and dung to cope with fuelwood scarcity

- Feeding animals with maize husks, maize stalks, groundnut stalks, shrubs, sweet potato leaves, banana leaves

- Adopting agricultural intensification technique, e.g. the widely promoted Sasakawa 2000 system, which involves higher planting densities.

- Destocking to cope with shortage of grazing resources

Other socio-economic impacts of shifts in resource access rights and use relations revolved around increases in the labour burden arising from resource scarcity. Who would be most affected depended on gender division of household abour, with men most affected when it comes to sourcing timber for construction, whilst women would be most affected for the collection of fuelwood and water. Spikes in the labour burden in other activities deprived food production of adequate labour to result in food insecurity within the household - and this insecurity affects all within the household.

\section{“Societal Stakes” vis-à-vis Globalized Trade and Investment}

Governance of Public Goods vis-à-vis the Public Interest 
Societal stakes in the tobacco sector relating to public goods include the governance of financial and natural resources for the public interest.

\section{Financial resources of the state}

Subsidies and tax breaks have been the main incentives used by government to encourage the tobacco industry. ${ }^{2}$ The analysis of how financial resources are governed must therefore consider both investment incentives for those wishing to invest in the tobacco sector, as well as other subsidies provided to stimulate the sector.

Malawi provides a host of general incentives to investors, irrespective of the sector. These include the following:

- $100 \%$ investment allowance on qualifying expenditure for new building and machinery

- allowance up to $40 \%$ for used buildings and machinery

- $50 \%$ allowance for qualifying training costs

- allowance for manufacturing companies to deduct all operating expenses incurred up to 25 months prior to the start of operations

- loss carry forward of up to seven years, enabling companies to take advantage of allowances

- additional $15 \%$ allowance for investment in designated areas of the country such as Kanengo, Chirimba and Luwinga industrial sites

- free repatriation of dividends, profits, and royalties

For those companies establishing processing facilities in an export processing zone, a host of additional incentives also apply:

- zero corporate tax rate

- no withholding tax on dividends

- no duty on capital equipment, machinery and raw materials

- no excise taxes on purchases of raw materials and packaging materials made in Malawi

- no value added tax

No special incentives appear to apply to the agricultural sector outside of those related to manufacturing. ${ }^{3}$

The government has also provided a number of subsidies to the sector. In post-independence Malawi, government policies subsidized the costs of growing burley tobacco on large estates, reducing the cost of agricultural inputs, land, capital and labor (USAID, 1991). Smallholders were effectively excluded from these opportunities, with the main benefits accruing "in the public interest" being employment on large estates and indirect, macro-economic spin-offs associated with (reduced) revenue generation and exports. A series of World Bank loans were

\footnotetext{
${ }^{2}$ Malawi Tobacco Industry and the Environment. TED Case Studies No. 252. available at: http://www1.american.edu/TED/maltobac.htm (accessed Nov 21, 2010).

3 "Investment Incentives." Available at the Malawi Investment Promotion Agency website: http://www.malawiinvest.net/inves_incent.html (accessed Nov 21, 2010).
} 
also provided specifically for the tobacco sector from 1980 to 1990, during a time when production remained in the hands of large estates.

Following liberalization of the sector in the mid-1990s, through which smallholders came to dominate the industry (Jaffee, 2003), the government provided costly fertilizer subsidies to tobacco and maize farmers through the Agricultural Input Subsidy Programme (Dorward and Chirwa, 2011). An estimated US\$34,782,309 from the national treasury was provided to subsidize tobacco fertilizers in the 4-year period preceding $2009^{4}$. The recent cancellation of these subsidies has meant that farmers have to cover the full cost of production, which "placed the heavy burden of perpetual debt on farmers as they failed to settle loans to purchase farm inputs." Loan defaults, occurring on a significant scale, have subsequently threatened the sustainability of agricultural and rural finance in the country - causing the government to invest in credit repayment guarantees to input suppliers. The poor performance of these governmentbacked schemes has further contracted agricultural lending by the country's financial institutions (Jaffee, 2003), and resulted in limited societal benefits accruing from public finance.

It is interesting to note that the tobacco subsidies delivered as part of the input subsidy program program generated a derived demand for timber and is likely to have produced other environmental costs in the form of forest degradation (Chibwana et al, 2010) - a relationship which will be further discussed below.

\section{Natural resources}

The governance of natural resources - both land and state-managed forest reserves, also merits attention when considering the societal stakes associated with tobacco. As far as land governance is concerned, returns to labor and revenue per ha of land is of critical importance. As far as employment is concerned, tobacco reportedly generates employment in the order of 382 to 495 man-days per ha - much higher than many other staple and cash crops prevalent in the region (Keyser, 2002). Agriculture and forestry are also second only to manufacturing and mining in job creation in Malawi, with about two million of the country's 13 million people depending on tobacco and related industries for their livelihood (Government of Malawi, n.d.; Semu-Banda, 2010) ${ }^{6}$. However, remuneration per employee was lowest of all sectors (Government of Malawi, n.d.). Yet the concentration of tobacco production in the hands of smallholders ${ }^{7}$, coupled with the relatively high profitability of tobacco cultivation compared to other cash and food crops, means that returns to labor are in general high (Tobin and Knausenberger, 1998; Zeller, 1997 and Jaffee, 1997, cited in Jaffee, 2003).

\footnotetext{
${ }^{4}$ Calculated from data provided by Dorward and Chirwa (2011) and end-of-year exchange rates.

${ }^{5}$ Turmoil as Tobacco Prices Fluctuate, By Pilirani Semu-Banda. Available at: http://ipsnews.net/news.asp?idnews=42382 (accessed Nov 21, 2010).

${ }^{6}$ According to Mangisoni (2005), tobacco directly or indirectly supported between 7 and 8 million people per year from 2000 to 2005.

${ }^{7}$ Following policy reforms in 1990s, smallholders began to dominate the industry, with the average size of tobacco farms being 1.0 ha and the average tobacco field 0.2 ha. Only China rivals Malawi in this regard among major producer countries (Jaffee, 2003).
} 
As for revenue, tobacco has historically been the major contributor to government revenue, driving most government operations ${ }^{8}$ (Mangisoni, 2005; Nyasa Times, 2010). Yet with recent production and yield declines and reductions in auction and export prices, export earnings and gross revenues from tobacco are also declining. "Malawi is now devoting more of its relatively scarce land to a crop which is yielding less, not only in terms of physical product per area but also in terms of unit and absolute revenue, export earnings, and investable savings" (Jaffee, 2003: 28).

It is also important to look at the effects of the tobacco industry on national forest estate particularly that which is held by the state on behalf of citizens. It is by now well known that much of the tobacco expansion in Malawi and indeed globally has occurred through the direct displacement of woodlands. A study at the end of the 1990s found approximately 200,000 hectares of forests or woodlands to be removed by tobacco farming each year - with much of this occurring in the developing world (Geist, 1999). Tobacco-related deforestation $(44,000$ hectares) was also found to far exceed annual forest increases at the time (7000 hectares) (Ibid). In Malawi, tobacco was found to account for $20 \%$ of deforestation (Geist, 1998). A study in the early 1990s indicated that tobacco estates accounted for $21 \%$ of fuelwood consumption and around $47 \%$ of the deforestation caused by harvesting wood biomass for fuel (Moyo et al, 1993). Another study found Brachystegia woodland in Namwera (southern Malawi) to fall from 191,000 to 20,000 hectares in 20 years' time as a consequence of the tobacco industry (Geist et al., 2006).

While most of the deforestation in Malawi has been on customary rather than state land, a case study on wood sourcing practices by the tobacco industry found illegal sourcing practices to be rampant near Kasungu National Park due to feeble law enforcement (Mandondo et al, in prep). The government rule that flue cured tobacco growers should establish plantations on $10 \%$ of their estates has also reportedly failed to be enforced, something which is attributed to the "sensitive nature of the tobacco industry in Malawi" (Ibid). As woodlands on customary land deplete, pressure will inevitably be placed on public forest areas - raising a challenge for government to ensure societal benefits associated with tobacco cultivation do not result in the depletion of forests which the state must also manage in the public interest.

\section{Societal Externalities}

When looking at societal externalities, two critical issues stand out: macro-economic effects of the industry, and environmental externalities of national concern.

\section{Macro-economic effects}

The Malawian economy has an extremely high dependence on tobacco, with burley leaf accounting for 53 percent of Malawi's exports and over 70 percent of Malawi's foreign

\footnotetext{
${ }^{8}$ While recent statistics are hard to find, total tobacco taxes accounted for about $8 \%$ of all government tax revenue for the 1996/97 fiscal year (see: www1.worldbank.org/tobacco/pdf/country\%20briefs/malawi.pdf).
} 
earnings. ${ }^{9}$ The tobacco industry also contributes in the order of 34 percent to the Gross Domestic Product (Mangisoni, 2005) ${ }^{10}$. As stated by one analyst:

"The importance of tobacco to Malawi's economy cannot be exaggerated and there are relatively few examples elsewhere of a similar level of dependence on one sub-sector in a country's exports earnings, employment, and income flows. Tobacco accounts for some $60 \%$ of Malawi's merchandise exports, some $23 \%$ of its total tax base, and as much as $13 \%$ of its GDP. Many of Malawi's cities have been built by tobacco wealth while most of the few signs of 'prosperity' which one sees in rural Malawi .. have like-wise been substantially generated by tobacco-related incomes" (Jaffee, 2003: 3-4).

This view is corroborated by a study commissioned by the United States Department of Agriculture (Persaud and Saager Meade, 2009), which confirmed Malawi's tobacco exports to be positively related to its GDP and found no evidence that non-tobacco exports are a significant driver of economic growth in the country.

However, this high level of economic dependence on a single export commodity has a number of disadvantages. For any decrease in the world tobacco price, the more important the tobacco sector is in an economy, the worse the tobacco sector is hit (Diao et al, 2002). In such situations, declines in farmers' cash income were found to occur due to reduced export prices as well as the increased cost of inputs, which is in turn due to exchange rate depreciations (resulting from heavy reliance on tobacco exports). Proportionately greater losses were also found for smallholders relative to larger estates, making the economic burden of this finding most significant for poorer households. Declines in tobacco prices also had negative effects on the exchange rate, consumer price index, real GDP, exports and imports, and government revenue (Ibid). Another study found fluctuation in Malawi's tobacco exports to contribute to slow economic growth because the impact of tobacco exports on GDP is estimated to be almost three times greater when exports fall than when they rise (Persaud and Saager Meade, 2009). This "asymmetry" is caused by ineffective management of export revenues and production and marketing inefficiencies which reduce farmers' share of the export price ${ }^{11}$.

It thus becomes critically important for Malawi to diversify its export base. However, despite 30 years of trade preferences, Malawi has not been able to diversify its export base from its traditional exports - tobacco, sugar and tea (Mangisoni, 2005). Ironically, most analysts see any potential to diversify as depending on "the maintenance of a competitive and profitable tobacco subsector from which savings can be derived and invested in other economic activities" (Jaffee, 2003: 6). Productivity gains and reduced transaction costs within the tobacco supply chain are seen as critical pathways in this regard (Jaffee, 2003; Persaud and Saager Meade, 2009).

\footnotetext{
${ }^{9}$ CIA World Factbook https://www.cia.gov/library/publications/the-world-factbook/geos/mi.html

${ }^{10}$ The agricultural sector as a whole contributes about $39 \%$ to the country's GDP and $90 \%$ to its foreign exchange earnings (MAFS, 2010).

${ }^{11}$ Another study by the World Bank which explored the economic effects of tobacco control on national economies (benefits from employment and income, tax revenue and foreign exchange, and costs associated with public health costs) found that most nations would experience net economic gains if their demand for tobacco products fell, because economic losses would be offset by economic gains at household and national levels. However, Malawi is unique among those countries studied in the contribution of tobacco to total export revenues, the tobacco trade surplus and low levels of domestic consumption (and related health costs).
} 


\section{Impacts on environmental services of national concern}

Tobacco has a host of environmental effects that are of concern to society as a whole. These include air and water pollution and the loss of forest ecosystem services. Tobacco production consumes large quantities of fertilizers and pesticides, which when released into waterways affect aquatic ecosystems and the people who depend on them for their livelihoods (EPA, 1997). The manufacturing of cigarettes and cigars also produces large quantities of waste and results in air pollution (Novotny and Zhao, 1999). Flue-curing produces tobacco-specific nitrosamines when nitrous oxide (a product of combustion) combines with the nicotine in tobacco leaves. Proven carcinogens, these products are an important source of occupational and environmental cancer (Wu et al, 2004). Aldrin, dieldrin and DDT, largely banned in developed countries, are among the chemicals used in Africa. Methyl bromide, widely used as a fumigant in developing countries, contributes substantially to ozone depletion and is a toxic contaminant of groundwater (CDPR, 1994; EPA, 1997; UNEP, 1992). Tobacco also depletes soil nutrients at a much faster rate than many other crops, thus rapidly decreasing the fertility of the soil.

The aforementioned degradation of public forests together with the loss of large areas of customary forest has a significant effect on forest ecosystem services, including carbon sequestration, biodiversity conservation and watershed functions. One study found the conversion of forests to tobacco farms to lead the local disappearance of native flora and fauna (Olenga, n.d.). However, efforts by the government to promote burley over flue-cured tobacco varieties and the country's heavy reliance on the former represent an important step in reducing such environmental effects, as flue-cured varieties consume far greater amounts of wood in the curing process (Geist, 1997; Mandondo et al, in prep). This is presumably due to the shift to smallholder-based production $^{12}$. If one were to calculate the environmental burden per unit of tobacco output, it would likely point to large estates bearing much of the blame. A study on the effects of technology on forest diversity suggests that investments in production efficiency could also go a long way in reducing tobacco-induced deforestation and biodiversity loss (Sauer and Abdallah, 2007).

According to one estimate, if incorporated into the cost of manufacturing the end product, such environmental costs would increase the price of raw tobacco by $20 \%$ and the finished product by 40\% (De Riotta, personal communication cited by WHO, n.d.). Yet since these costs are not covered by producers, they are costs borne by Malawian citizens in the form of health care expenditures and a declining livelihood base.

\section{Conclusions}

A stock-take of the primary shifts in customary bundle of rights shows that smallholders arbitrarily displaced through the expansion ended up the major losers. Land loss drastically collapsed landholdings, depleted household livelihood portfolios, reduced crop diversification, spiked the household labour burden, increased the commercialization of land, etc - resulting in opportunity costs far too high to be adequately offset by efforts people made to rebuild their lives. Up until liberalization, white, and then black elites, remained the primary beneficiaries of

\footnotetext{
${ }^{12}$ Flue-cured tobacco, which requires higher investments in processing, is grown primarily by medium and especially large-scale estates (Jaffee, 2003).
} 
tobacco expansion in that country. Moreover, liberalization only addressed strictures in market access suffered by the poor, and not the iniquities of a double expropriation, manifesting through loss of land and related shifts in resource rights. These iniquities will continue to persist for as long as win-win solutions are not found.

The situation in Malawi cries out for viable strategies to address land hunger and resource hunger, particularly among those who lost their land unfairly to estates without any semblance of recompense. The existence of derelict land on parastatal and elite estates from which people were formerly displaced - presents a "low hanging fruit" for instituting a pro-poor land reform programme. Reuniting land losers with their agrarian heritage requires affirmative action going beyond giving them the option of 'first refusal' of land reverting to the state after expiry of existing leases, as envisaged in the new land policy (Government of Malawi 2002). It should be a programme restitution without economic strings attached. Most of these leases were awarded under the pretext that the customary lands in question were unutilized, which is clearly not true in the majority of the cases. A pro-poor land reform programme should however not be construed as anti-market as a market in land could still be made to operate in such a way that benefits accrue to victims of land loss, if it is their choice to commercialize the land and not to take direct possession of it.

Where land redistribution appears unfeasible, given the strategic importance of tobacco in the country, targeted social spending could be considered, presumably based on a commodityspecific approach. Financial resources for such programmes could be generated from targeted restitution and rehabilitation taxes imposed on estates benefiting from holding land at the expense of local communities. The land policy also needs to be appropriately aligned such that revenues accruing to the government through the creation of customary leasehold estates get channeled to communities rather than to the government (e.g. see Government of Malawi 2002). Most of the above recommendations revolve around internalizing the externalities associated with the commodity's production.

The terms of investment that the Malawi government has put in place to attract investments appear very generous, particularly for the tobacco sub-sector. Significant inflows of investments have been registered in response to the favourable environment for investment, albeit at expense to the physical and other environments. Tobacco's impacts on forests and the environment are the most stubborn at defying the confines of space and scale. Although laws envisioning the replacement of forests denuded through tobacco expansion exist these suffer from poor enforcement. Lack of parity between very attractive terms of investment and laws intended to ensure that the commodity is produced in a socially and environmentally 'responsible' manner imply that producers (particularly the big ones) win in a big, albeit artificial way. This is not least because the huge benefits realized mostly accrue from subsidies from forests, the environment and the poor - which remain the biggest losers.

Generous tax-inducements to lure investment should be coupled with viable penalties to ensure the benefits accruing to key actors within sub-sector are directly tied to correlative sets of costs 
in line with the 'polluter pays' principle. Related international governance instruments intended to balance the distribution of externalities associated with global "public goods' have emerged and hold scope for addressing local environmental concerns with a 'public goods' scope - e.g. payment for environmental services schemes (Pagiola et al 2002). Thinking, therefore, needs to be scaled down to the perspective of how owners of estates can be made accountable, financially or otherwise, for the impacts that their activities directly engender among surrounding communities and ecosystems (e.g. see Wunder 2005). Such schemes will, however, need to be introduced with caution and in an incremental manner, starting with areas holding promise for more immediate success, so as to avoid triggering investment flight.

Its social and environmental impacts notwithstanding, tobacco remains the cornerstone of the Malawi economy, where it registers substantial gains in terms of contribution to GDP, export earnings, employment, balance of trade and other indicators. This upside about tobacco in the Malawi economy also represents its major downside, with the economy left highly vulnerable to the vagaries of fluctuations in global demand and prices of the commodity, as well as related input prices and exchange rates (Jaffee 2003). Grandiose plans for diversifying the economy have been attempted or mooted, including building of an inland port along the Shire river in the south - with impacts minimal or still be to be fully ascertained. "Small is beautiful" approaches may consider building upon the country's present strengths, with tax breaks being considered for those investing in tobacco but quickly diversifying into other areas upon the tolling of specific time periods.

The above proposal is rendered unattractive by the extent to which the country's economy is dependent on tobacco, which Jaffee (2003) likens to "standing on one strong leg", with $23 \%$ of the country's tax revenues accruing from the tobacco industry. But the risk posed by 'standing on one leg' stands confounded by the sheer magnitude of people on the government payroll, which features even more people than those reported to be involved in producing the crop. Related concerns that the government is 'over-milking its cash cow' may therefore not entirely be unfair. Streamlining the civil service as an option may however threaten interests that may well lie beyond the merely economic.

\section{References}

Bunderson, W.T. and Hayes, I.M. 1997. Sustainable tobacco production in Malawi: the role of supply and demand. Paper presented at the seminar on "Malawi Tobacco and the Future", Club Makokola, Mangochi. October 1997.

California Department of Pesticide Regulation - CDPR. 1994. 'Methyl bromide.'

Chibwana, C., Jumbe, C., and Shively, G. 2010. Measuring the Forest Impacts of Maize and Tobacco Subsidies in Malawi. Purdue University, West Lafayette, IN. 
Colchester, M. and Ferrari, M. 2007. Making FPIC Work: Challenges and Prospects for Indigenous Peoples. Forest Peoples Programme, Moreton-in-Mash.

Diao, X., Robinson, S., Thomas, M. and Wobst, P. 2002. Assessing impacts of declines in the world price of tobacco on China, Malawi, Turkey, and Zimbabwe. TMD Discussion Paper No. 91. IFPRI, Washington, D.C.

Dorward, A. and Chirwa, E. 2011. The Malawi Agricultural Input Subsidy Programme: 2005-6 to 2008-9. Forthcoming in the International Journal of Agricultural Sustainability, Volume 9(1), January 2011.

EPA. 1997. Methyl bromide use. EPA, Washington, D.C.

French, D. 1986. Confronting and unsolvable problem: deforestation in Malawi. World Development 14(4): 531-540.

Geist, H. 1997. How tobacco farming contributes to tropical deforestation. Paper presented at the Tobacco Deliberation Group Meeting, National Committee for International Cooperation and Sustainable Development, Utrecht, 29 October 1997.

Geist, H.J. 1998. Tobacco: A driving force of environmental change in the Miombo Woodland Zone of Southern Africa. Paper presented at the conference African Environments: Past and Present. Department of Geography, 11 August 1998. Oxford University Press; 1999.

Geist, H.J. 1999. Global assessment of deforestation related to tobacco farming. Tobacco Control 8(1999): 8-28.

Geist, H., Otanez, M. and Kapito, J. 2006. The tobacco industry in Malawi: a globalized driver of local land change. In Lambin, E.F. and Geist, H. (eds) Landuse and Land Cover Change: Local Processes and Globalized Impacts, pp251-268. Springer, Berlin.

Gossage, S.J. (1997): Land use on the tobacco estates of Malawi. Report of the land use survey of tobacco estates in Malawi 1996. - Estate Land Utilisation Study (ELUS): Lilongwe

Government of Malawi (2002) Malawi National Land Policy. Ministry of Lands, Physical Planning and Survey, Lilongwe.

Government of Malawi. n.d. Annual Economic Survey 2005 - 2006. Lilongwe: National Statistics Office. Available at: http://www.nso.malawi.net/data_on_line/economics/aes/ Final\%20Report\%202005-2006.pdf (accessed Nov 20, 2010).

Jaffee, S. 2003. Malawi's tobacco sector: Standing on one leg is better than none. Africa Region Working Paper Series 55. World Bank, Washington D.C. 
Keyser, J.C. 2002. The costs and profitability of tobacco compared to other crops in Zimbabwe. Economics of Tobacco Control Paper No. 1. HNP Discussion Paper. World Bank, Washington, D.C.

Koester, U., Olney, G., Mataya, C. and Chidzanja, T. 2004. Status and prospects of Malawi's tobacco industry: a value chain analysis. A report prepared for the Emergency Drought Recovery Project, Ministry of Agriculture, Lilongwe.

Maleta, M. 2004. Malawi - Tobacco sector performance audit: review of the performance of sector institutions. Report prepared for the Emergency Drought Recovery Project, Ministry of Agriculture, Lilongwe

Ministry of Agriculture and Food Security - MAFS (2010) A Medium Term Plan for the Farm Inputs Subsidy Programme (2011-2016), Third version. Lilongwe: Ministry of Agriculture and Food Security.

Mandondo, A., German, L., Utila, H. and Nthenda, U.M. In prep. Assessing Societal Benefits and Trade-offs of Tobacco in the Miombo Woodlands. CIFOR Working Paper.

Mangisoni, J.H. (2005) An economic analysis of the value of agricultural trade preferences to Malawi: A case study of the tobacco, tea and sugar industries. African Crop Science Conference Proceedings, Vol. 7. pp. 797-801.

Matthews, A., and Wilshaw, C. 1992. Fodya: The Malawi Tobacco Handbook. Central Africana Limited, Blantyre.

Moyo, S., O'Keefe, P. and Sill, M. 1993. The Southern African Environment: Profiles of the SADC Countries. ETC Foundation and Earthscan, London.

Murphree, M.W. and Cumming, D.H.M. 1991. Savanna land use policy and practice in Zimbabwe. Paper presented at the UNESCO/IUBS Conference on Savanna Landuse. Nairobi, January 1991.

Novotny, T. and Zhao, F. 1999. Consumption and production waste: Another externality of tobacco use. Tobacco Control 8(1999): 75-80.

Nsiku, N. and Botha, W. 2007. Tobacco revenue management: Malawi case study. International Institute for Sustainable Development, Winnipeg, Manitoba, Canada.

Nyasa Times. 2010. 'Malawi coaxes tobacco producers to fight G20.' Available at: http://www.nyasatimes.com/national/malawi-coaxes-tobacco-producers-to-fight-g20.html

(accessed 21 Nov 2010). 
Olenga, S. DATE. Biodiversity losses due to tobacco cultivation: A case study of deciduous forest ecosystems in Tanzania. Oxford Forestry Review 11: 4.34-4.39.

Pagiola, S., Bishop, J. and Landell-Mills, N. (eds) Selling Forest Environmental Services. Market-based Mechanisms for Conservation and Development. Earthscan, London.

Poulton, C., Kydd J. and Kabame, D. 2007. Review of experiences with commercial agriculture: case study on Malawi tobacco: Centre for Environmental Policy, Imperial College, Kent.

Torbin, R.J. and Knausenberger, W.I. 1998. Dilemmas of development: Burley tobacco, the environment and economic growth. Journal of Southern African Studies 24(2): 405-424.

Schlager, E. and Ostrom, E. 1992. Property-rights regimes and natural resources: A conceptual analysis. Land Economics 68(3): 249-262.

Semu-Banda, P. n.d. 'Turmoil as Tobacco Prices Fluctuate'. Available at: http://ipsnews.net/news.asp?idnews=42382 (accessed Nov 21, 2010).

Tsonga, E.W. 2004. An analysis of the performance of Malawi's tobacco production and exports. A report prepared for the Emergency Drought Recovery Project, Ministry of Agriculture, Irrigation and Food Security.

UNEP. 1992. The impact of ozone layer depletion. UN Environment Programme.

USAID. 1991. Agricultural Sector Assistance Program, Vol. I. USAID-Malawi, Lilongwe.

Vermeulen, S.J. and Cotula, L. 2010. Over the heads of the people: consultation, consent, and recompense in large scale land deals for biofuels in Africa. Journal of Peasant Studies 37(4:): 899-916.

World Bank. 2003. The Economics of Tobacco Use and Tobacco Control in the Developing World. Brussels: EC, WHO and World Bank.

World Health Organization (n.d.) Ecological and Environmental Effects of Tobacco Use. In: Economic, Ecological and Environmental Effects of Tobacco Use, pp. 139-149. Available at: http://www.whoindia.org/LinkFiles/Tobacco Free Initiative 03-Chapter-05.2.pdf (accessed Nov 20, 2010).

$\mathrm{Wu}, \mathrm{W}$, et al. 2004. Assessment of tobacco-specific nitrosamines in the tobacco and mainstream smoke of bidi cigarettes. Carcinogenesis 25: 283-287.

Wunder, S. 2005. Payments for environmental services: some nuts and bolts. CIFOR Working Paper 42. Centre for International Forestry Research, Bogor, Indonesia. 
